\title{
Garrett Bunyak
}

\section{Will Curiosity ${ }^{\circledR}$ Kill the Cat?: Technoscience and Free Living Cats "Down Under"}

Eradicat ${ }^{\circledR}$ is a twenty-first century technoscientific implosion of kangaroo flesh, chicken fat, flavor enhancers, nationalist zeal, and sodium monoflouracetate. With the stated goal of protecting bird populations, toxic Eradicat ${ }^{\circledR}$ sausages and the similar Curiosity ${ }^{\circledR}$ bait are designed to kill free-living cats with poisons such as the synthetic Compound 1080 (sodium monoflouracetate), a chemical offspring of World War II developed in the United States in response to Allied forces encountering rat-borne diseases (Ward and Spencer). Justus Ward, a pharmacologist for the U.S. government, quickly wrote in 1947 of "one of the most serious disadvantages of the poison" being that "dogs and cats are killed by eating sick or dead rodents killed by 1080" (1430). Over the next several decades, partly in response to concern for endangered bird populations, compound 1080 would be weaponized to kill free living cats marked as "alien," "invasive," and "feral." This genealogy of a contemporary war against cats traces changing relationships among colonists, cats, birds, and toxins, especially focusing on the increasing importance of technoscience in mediating these relationships in postcolonial Australia and New Zealand. ${ }^{1}$ The paper follows the accounts of scientists including biologists, naturalists, and ecologists to reveal legacies of colonialism, imperialism, and human exceptionalism that haunt and naturalize these lethal entanglements of scientists, kangaroo flesh, sentiments, poisons, birds, and cats.

The "domestic wild cat" is paradoxical, but the irony reflects a situation that allows cats to be both loved as companions and exterminated as pests. In Australia, for example, the free-living cat as a "feral," "alien," and "invasive" being is a threat to "natural" ecosystems. The cat as invasive species is marked for extermination and eradication. "Invasive" and "alien" cats have not conformed to the acceptable spatial boundaries defined by people that increasingly define the "natural" location for domestic cats as indoors. Although Europeans released domestic cats in places such as Australia and New Zealand during colonization to control rodent populations, human exceptionalism propels scientific endeavors to continually intervene in ecosystems with little consideration of the unintended and ironic consequences of Western rationality and "progress." With these dynamics in mind, the history of human-felid entanglements is a useful story to examine the ongoing construction of "progress," "rationality," and "nature" with and through systems of representation and technoscience. 
This paper begins with a discussion of literature at the intersections of posthumanism, Science and Technology Studies (STS), and animal studies before turning to a discussion of the use of genealogy as methodology. Then, the history of human relationships with free-living cats in postcolonial Australia and New Zealand is read through accounts of historians, ecologists, and biologists, critically focusing on several contexts that have naturalized deadly human-felid entanglements in the twenty-first century. First, within the representations examined here, humans have been constructed as metaphysically superior to other species, especially by constructing "rationality" as a uniquely "human" characteristic. Second, rationality is constructed as a means to control and master populations of cats and birds as well as entire ecosystems and is naturalized as a desirable social and scientific pursuit. Third, science is represented as the ultimate mechanism for progressing towards more perfect control of the "domestic wild cats" considered here and "nature" more broadly. My analysis suggests practicing science to control ecosystems and "nature" is an unreasonable pursuit stained with legacies of colonialism, nationalism, and speciesism. The lethal consequences for non-human animals and indigenous people are discussed. Most importantly, a science geared toward the control of the non-human world may be a greater threat to planetary wellbeing than many of the short-term problems science is working to solve. The current analysis extends interdisciplinary scholarship in STS through an historical examination of a particular scientific effort to control ecosystems and animal populations.

Posthumanism and human-cat entanglements. In many former colonies, historians suggest the domestic cat is a product of colonialism (Faure and Kitchener; Koch et al.). European colonizers are said to have used cats to control pests onboard their ships and brought felids to their settlements (Faure and Kitchener). Human-feline relations changed in the nineteenth century, according to Katherine Grier, as middle-class families in the United States began to consider "pet keeping" as a "morally purposive act" rather than a "personal indulgence" (2). Companion animals began to be used to instruct children, especially young boys, regarding the virtues of "kindness and sympathy" to "create good men in a culture that worried a great deal about the nature of manhood itself" (19).

Colleen Glenney Boggs suggests these developments might be traced back to the pedagogy of John Locke, specifically the idea that humane treatment of animals will ensure "human beings will treat each other with compassion" (140). Boggs analyzes Locke's position, suggesting that although "Locke's emphasis is on the way human beings treat each other, his argument depends on the substitution of animals for human beings: being cruel to animals results in being cruel to other human beings; the two are

Humanimalia: a journal of human/animal interface studies

Volume 10, Number 2 (Spring 2019) 
not separate from one another but, on the contrary, lie on a continuum" (Ibid.). Here, Boggs lays the groundwork for a relational approach in which "we do not know - a priori or, for that matter, a posteriori - what or who 'the animal' or 'the human' is because such definitions emerge in a complex matrix of intimacies and representations; that is, they enable us to abandon the realm of ontological difference and locate us productively in the terrain of epistemological uncertainty" (188). Boggs is able to focus her resulting literary analysis on investigating the historical construction of "humans" and "animals" in the works of Emily Dickinson, Barbara Bush, and Edgar Allen Poe.

In the West, the dominant construction of human-feline relationships is a humanist portrayal of a rational, responsible human "owner" and an instinctual "less than human" animal other (Collard; Bunyak). In this story, humans are granted reason, rights, and responsibilities including the responsibility to care for the companion animal other, presumably because the companion animal is less than human and lacks some allegedly unique human capacity (Collard; Cudworth). Humans are often constituted in these representations as "caring" and "responsible" subjects, reifying longstanding notions of humans as stewards or caretakers of the more natural animal world. Companion animal relationships have been important sites of analysis to examine the negotiation of the oft-critiqued human-animal and nature-culture binaries (Haraway, Companion Species; Haraway, When Species Meet; Bunyak). As will be discussed below, the construction of felines as "less than human" family members also enables alternative constructions of cats as pests, ferals, and "invasives" because they are "othered" as less than human.

Humanist ways of thinking assume a metaphysically privileged human. As a result, animals are excluded from full political and ethical consideration and "refused speech, reason, morality, emotion, clothing, shelter, mourning, lying, lying about lying, gifting, laughing, crying - the list has no limit" (Collard 40). For geographer Rosemary Collard, denying nonhuman animals status as subjects enables "multi-species dispossession on a grand and systematic scale" (36). Often, humans are constructed as superior through recourse to an allegedly unique human capacity for "rational" thinking. The rational mind of the Enlightenment, as philosopher David Abram writes, "looks upon nature from a cool, detached position ostensibly outside of that nature" in pursuit of "its giddy dream of comprehending, and mastering, every aspect of the material cosmos" (108). As used here, humanism assumes "humans" possess a unique capacity for rational thought, despite the growing body of animal studies research that increasingly illustrates the ability of animals to solve problems, share material culture, and communicate using non-human languages (Shew). 
The characterization of the human scientist as rationally pursuing knowledge is long exemplified throughout Western science. For example, the nineteenth century physiologist Claude Bernard, known as the "prince of vivisectors," disturbingly situates the rational scientist as detached from the material world as "he" works only in the realm of ideas, in the mind, when Bernard writes, "the physiologist is not a man of the world, he is a scientist, a man caught and absorbed by a scientific idea.... He no longer hears the cries of the animals, no longer sees the flowing blood; he sees only his idea... he pursues with delight a nervous filament inside stinking and livid flesh that for any other person would be an object of disgust and horror" (103). Bernard's male scientist retreats from the stink of material reality to the mind, a realm of ideas, reason, and objectivity.

In contrast to the detachment from experiments that continues to pervade scientific writings, activists read interspecies experimentation more critically. The American AntiVivisection Society claims 24,564 cats were used in laboratories in 2012, and 9,272 cats were subjected to experiments which caused pain and distress. For some researchers, the domestic cat is considered an important tool in experimentation in neurology, ophthalmology, and immunodeficiency because "cat brains are the closest match we can find without resorting to people" (Suzdaltsev). The AAVS argues that often "research is extremely invasive, and almost always results in the euthanasia of the cats after they are subjected to grueling vivisection procedures." In 2017, People for the Ethical Treatment of Animals (PETA) lambasted experiments at the University of Wisconsin-Madison because researchers "drill holes into cats' skulls, implant electrodes in their brains, and implant steel coils in their eyes ... cats are intentionally deafened and then killed." In challenging the torture and killing of these animals for science, PETA argues that "these cats are just as deserving of fulfilling lives and loving homes as the feline companions who purr on our laps" (1-2).

Notwithstanding outrage from animal rights groups, violent experiments on animals have led to the highest levels of recognition within science, including the Nobel Prize received by David Hubel and Torsten Wiesel in 1981. Part of Hubel and Wiesel's awardwinning research involved the deprivation of kittens' use of one eye by sewing the eye shut to examine the consequences of unilateral vision on the visual cortex in the brain. The suturing of kittens' eyes resulted in blindness, but the research is said to have helped ophthalmologists to better develop protocols and recommendations for surgical treatment of diseases such as congenital cataracts. Praise of Hubel's work in the field of neuroscience continued after his death in 2013 as evidenced by post-humous

Humanimalia: a journal of human/animal interface studies

Volume 10, Number 2 (Spring 2019) 
commendation of him as "the man who developed our understandings of vision" that failed to acknowledge the terror and violence imposed on the felines that helped shape these discoveries (Grzybowski and Pietrzak). Lavishing praise upon these scientists fuels a drive for continued growth and progress within the allegedly detached sciences. Although animal experimentation and cruelty face increasing scrutiny in many circles, experiments such as those at Wisconsin-Madison suggest experimentation continues to abide by the logics of progress and human exceptionalism.

Despite metaphysically privileging the "human," as Boggs writes, "human exceptionalism ultimately does not protect human beings from abjection but enables abuse by creating a position of animality that is structurally opposed to humanity" (42). Animality "collapses distinctions between humans and animals" because human beings can inhabit the "structural position" of animality (49). As Boggs points out, early colonists "animalized" indigenous Native Americans as "beastlike," excluding them from ethical consideration that may have prevented their eventual annihilation. Just as humans can be "animalized" animals can also be "humanized," as evidenced by the optimization of furry companion animal "family members" with and through contemporary veterinary medicine (Bunyak). In deploying notions of an "animalized human" and "humanized animal," Boggs extends posthumanist work seeking to challenge and destabilize the binary categories of human-animal. With these dynamics in mind, Erika Cudworth suggests human exceptionalism has produced "disastrous consequences for many peoples and non-human life worlds" and advocates for conceptualizing ways "oppressions of human and non-human animals are intersected" (253).

In response to longstanding intellectual recourse to humanist ways of knowing and being, scholars have deployed a posthumanist analytic to undertake several ontological moves, including extending ethical consideration and "subject status" to non-human lives and forms, destabilizing common sense understandings of the categories of human and animal, and rejecting a priori metaphysical privileging of humans ${ }^{2}$ (Haraway, When Species Meet; Boggs; Cudworth; Weston; Puig de la Bellacasa; Frost; Bunyak). In part, posthumanisms continue to destabilize the categories of "human" and "animal" and to encourage an examination of the processes that contribute to giving specific meaning and coherence to the notion of being either "human" or "animal." Yet, posthumanisms are concerned with more than meanings. As used here, posthumanism is concerned also with the ways meanings and discourses are constitutive of the embodied materialism and situatedness of being "animal" or "human" in lived social worlds. Boggs points to 
this co-production in describing "animal representations" as "an interface where the literal and symbolic meet and unsettle the terrains of modern taxonimization" (189).

The production of "nature" is also at stake with and through cultural processes, as posthumanisms emphasize the concept of "naturecultures" (Haraway, When Species Meet; Subramaniam). In her recent research on invasion biology, Banu Subramaniam rejects appeals to "nature" that make recourse to romanticized visions of an idyllic utopia before humans conquered and spoiled the wild. In contrast, Subramaniam describes nature "as a concept, an idea, and a place that is co-produced through the interaction and entanglements of various organisms, histories, and geographies" (96). In deploying this definition, Subramaniam rejects descriptions of "native" and "invasive" species as historically and culturally arbitrary, especially in a world with "profound human-induced movements of flora and fauna" (138). She aptly states, "whether we like it or not we are defining nature through our actions" (141).

Possums, for example, were released into New Zealand by humans for the purposes of commercial exploitation, resulting in clear changes in New Zealand ecologies as possums flourished in their new environments. Annie Potts points out possums are now widely represented in news reports, magazines, television, and children's literature as "foreign invaders" that are "cute" but "lethal" (202). In deploying the language of invasion, possums are constructed as independently infiltrating New Zealand's borders when "the truth is they are as much victims of human colonization and exploitation as the native species of Aotearoa" (224). Potts suggests "the public dislike of possums ... does not come 'naturally.' Instead it must be programmed into children from an early age" (218). Anti-possum sentiment fuels and naturalizes a figurative and literal war on possums. As Potts points out, however, alternative stories of possums unsettle and denaturalize these relations by constructing possums as worthy of compassion and deserving of respect. The introduction of possums for commercial benefit and an eventual war on possums illustrates that interactions between humans and other species co-shape changing naturalcultural worlds.

Subramaniam goes on to suggest that "the invasive species 'war' reflects our continued ambivalence about immigration" and nationalist ideologies (120). She suggests "the battle against exotic and alien" flora and fauna maps onto broader anxieties about "economic, social, political, and cultural changes" (121). She continues:

The categories of native and foreign are not useful. Instead let us focus on ecological traits that cause change we find undesirable and on the causes

Humanimalia: a journal of human/animal interface studies

Volume 10, Number 2 (Spring 2019) 
of these changes that we should be actually worried about - destruction of habitats, erosion of diversity, soil erosion, overdevelopment, monocultures, high input agriculture, pollution of air and water. And above all let us be clear that our choices are "human made" whether for economics, aesthetics, or enhancement of particular ecological characteristics like biodiversity, harmony, and species richness that humans have deemed important. (141)

In situating humans as a part of, rather than detached from, nature, a posthumanist analytic is useful to contest and challenge anthropocentric efforts to control the nonhuman world and the related tropes of progress and reason.

The liminal status of the "domestic wild cat." Archaeologists suggest cats began a commensal relationship with humans up to 12,000 years ago in the Middle East alongside the development of agricultural societies in the Fertile Crescent (Driscoll, Macdonald, and O'Brien; Faure and Kitchener). The storage of excess grains is said to have attracted mice and rodents, which in turn drew middle-eastern wildcats more closely to human villages. Scientists point to the discovery of a cat buried alongside a human companion around 9,500 years ago in Cyprus as some of the earliest evidence of a commensal relationship between the two species (Driscoll et al.; Faure and Kitchener). The relationship is often represented as mutually beneficial because cats seemingly benefited from abundant food sources and humans benefited from the control of graineating rodents in "one of the more successful 'biological experiments' ever undertaken" (Driscoll et al. 522).

Considering thousands of years of "evolution," Driscoll, Macdonald, and O'Brien suggest the most "notable adaptation is the cat's overwhelming tolerance of people," which "has made cats the delightful and flourishing profiteers in our homes that they are" (9977). At first glance many cats "profiteer" within human homes, but on closer inspection human-feline relations continue to be fraught with contradictions, contestations, and ambivalences. Alongside Driscoll's optimistic evolutionary tale of furry pets living in safe health-promoting confines of the contemporary middle-class homes, Jody Berland writes "no animal in history has been so routinely murdered, tortured or massacred as the domestic cat" (434).

These contradictory narratives are worth exploring in a little more detail. In the twentieth century, technological advances such as refrigeration and the invention of kitty litter are said to have laid the groundwork for a recent parade of cats into the confines of human homes in the second half of the century (Robins). According to the 
Australian Companion Animal Council, 29\% of Australian homes "own" at least one cat and around 3.3 million are kept as pets in 2018. Cats are even more popular in New Zealand, as cats can be found playing and sleeping in $44 \%$ of homes and over eight out of ten cat owners in New Zealand consider their pets to be a family member (New Zealand Companion Animal Council). The pet industry is booming - consumers spent 4.6 billion Euros in the U.K. in 2016, 66.75 billion U.S. dollars in the United States in 2017, an estimated 8 billion Australian dollars annually in Australia, and nearly 1 billion New Zealand dollars in New Zealand each year (American Pet Products Association; New Zealand Companion Animal Council). The optimization of companion animal well-being is a major goal of the Western veterinary apparatus, as the responsibility of the owner to enhance the lives of companion animals fuels a growing pet industry (Bunyak). The American Association of Feline Practitioners (AAFP) and American Animal Health Association's (AAHA) “Feline Life Stage Guidelines” suggest veterinary medical teams should provide "recommendations for optimal health care for cats throughout the different life stages" (Vogt, et al.). The AAFP-AAHA guidelines recommend a minimum of one annual wellness exam for feline companion animals. During wellness examinations, veterinarians are encouraged to discuss a range of technoscientific healthcare and behavioral management topics, including microchipping, medications, supplements, sterilization, body composition score, dental care, nutrition, feline weight, and vaccinations.

Alongside the expansion of a veterinary apparatus serving people, cats, and capital, it is important to additionally note that six to eight million cats and dogs enter shelters in the United States each year, and 3 million cats and dogs are killed each year in shelters alone, with about $80 \%$ of them healthy (Humane Society of the United States). In the U.S., six out of ten pet owners consider their pets a family member - yet their status outside of the position of humanity makes the bodies of unwanted cats killable. Although the numbers are less imposing, thousands of cats and dogs are killed by RSPCA Australia annually (RSPCA Australia).

Part of the justification for the destruction of "domestic wild cats" is that, in many scientific discourses, cats' lives are marked as "invasive" and "alien," and this has deadly consequences. As will be discussed, free-living cats across Australia are annihilated with and through science at the same time as humans pamper their indoor companions. Before discussing this dynamic further, I next outline key components of the genealogical analysis that ground the method used in this essay.

Humanimalia: a journal of human/animal interface studies

Volume 10, Number 2 (Spring 2019) 
Genealogical analysis. For Michel Foucault, genealogy attempts "to desubjugate historical knowledges, to set them free, or in other words to enable them to oppose and struggle against the coercion of a unitary, formal, and scientific theoretical discourse" (10). In other words, genealogy is a method that seeks to reveal the resistance, struggle, and messiness that is smoothed over and obscured within discourses of science, progress, and reason. Genealogy shows that "power creates illusions" by "deciphering," "outwitting the ruse," and reclaiming "knowledge that has been distorted or buried" (Foucault, 72). Anthony Hatch describes the Foucauldian methodology:

Genealogy ... traces the emergence and descent of technologies and practices used to produce discourses about the body and the political contexts through which these elements are constructed as self-evident, natural, and universal. Genealogy is also a form of political critique that diagnoses how such discourses, practices, and technologies are embedded in and rationalize unequal power arrangements. The intellectual and political intent of genealogy, therefore, is to contest discourses that are used to instantiate, enable, and support repressive and/or productive forms of modern social power by showing how those discourses have determined (in a limited way) what constitutes our present understanding of ourselves, our social world, and the social relationships therein. (12)

Technoscience, in the approach used here, encompasses assemblages of animals, persons, knowledges, instruments, and scientific representations that are organized by certain, historically specific social goals (Rose).

With this in mind, genealogy enables an examination of the discourses that legitimize the exercise of power, knowledge, and domination in contemporary efforts to eradicate free-living cats in Australia. The analysis pays particular attention to the historical narratives of reason and progress used to legitimize and promote the eradication of felids through increasingly advanced technoscientific instruments, such as Eradicat ${ }^{\circledR}$ and Curiosity ${ }^{\circledR}$ baits. As will be discussed, certain scientific discourses clearly legitimize and naturalize unequal power relations within and between species, and these dynamics are shown to be in flux. In this genealogy, the relationship between discourse and materiality is conceptualized as co-constituted, as suggested by Donna Haraway in writing of a process whereby "the imaginary and the real figure each other in concrete fact" (Modest Witness 2). In this case, the scientific mission to control feral cat populations loops back to shape ecologies based on changing social notions of the way "nature" should be, even as other species resist scientific interventions. 
Every genealogy is limited in scope. This paper focuses on the critiques the posthumanist analytic offers in relation to humanist ways of thinking to reveal the colonialist and human exceptionalist legacies that pervade the examined scientific representations through tropes of progress and reason. The data for this analysis are mostly collected from scientific journals in fields including ecology and biology. Data were also collected from more widely distributed and accessible popular news reports and articles, including several written by academics. Data collection and analysis were simultaneous and continuous throughout the research process, as new data often pointed the author towards novel and interesting developments related to the history of the project of controlling feral cat populations.

As discussed below, cat eradication efforts are intertwined with concerns regarding apparent declining bird and mammal populations. As used here, the genealogical method is not suited to adjudicate the tensions between the desire to protect threatened species with the desire for the "humane" treatment of cats or any other animals. The intention here is to examine the ways these scientific discourses are co-shaped alongside continually changing naturecultures, especially focusing on the production of inequities within and between species, as well as the known and unknown consequences of scientific efforts to control and master the material world.

Cats, birds, and the rational human. In Australia, the domestic cat is now considered a major threat to "native" ecologies and "local" fauna. The federal government approved a five-year plan in 2015 with a budget of $\$ 4$ million dollars to kill free-living cats (Commonwealth of Australia). The domestic cat was brought to Australia and New Zealand by European settlers during colonization throughout the eighteenth- and nineteenth centuries, probably to assist humans in the control of rodent populations (Faure and Kitchener; Koch et al.; Cushing and Markwell). At first glance, the transport of cats for purposes of pest control or companionship may appear "rational," but with the benefit of hindsight this action is problematized by considering the eventual ecological consequences and ultimately the rise of an entire scientific apparatus aimed at destroying the very cats Europeans brought with them as colonists. The first irony in the history of efforts to eradicate free-living cats for ecological and aesthetic purposes is that these cats were originally brought by colonists to control other animals for these very purposes. The actions of these humans represent an aspect of human exceptionalism, because the forced transport of felids assumes a human privilege to master and control non-human others, at least for the "humanized" British immigrants that leveraged the predatory abilities of felines to control rodent populations.

Humanimalia: a journal of human/animal interface studies

Volume 10, Number 2 (Spring 2019) 
Indigenous peoples were not afforded the same "humanized" status as Aileen MoretonRobinson describes the situation in Australia:

The first wave of invading white British immigrants landed on our shores in 1788. They claimed the land under the legal fiction of Terra Nullius land belonging to no one - and systematically dispossessed, murdered, raped and incarcerated the original owners on cattle stations, missions and reserves. In all these contexts the lives of Indigenous people were controlled by white people sanctioned by the same system of law that enabled dispossession. (24)

Indigenous people were "animalized" in order to justify their rape, murder, and abuse. Flogging, for example, was justified "on the basis of the supposed animality of the native, and the attendant belief that the savage was closer to nature, possessed a stronger tolerance to pain, and therefore a denser corporality that beckoned harsher measures" (Wadiwel 49). As a pastoralist reportedly suggested, "a native had a hide, and not an ordinary skin like human beings" (Hasluck 193). The "rational human" during colonization was precisely a white European man, as even the companion feline invaders were in some cases treated better than indigenous people by the colonizers in these years.

As colonists invaded, "native, non-human animals" were often "disparaged as unproductive and unpalatable oddities, killed as competitors to introduced species, or harvested as a source of fur and feathers for export," and British colonists also engaged in keeping and commodifying "native" Australian mammals and birds as "pets" including "the grass or shell parakeet, cockatoos, rosellas, lorikeets, and cockatiels" (Cushing and Markwell 592, 596). During these times, colonists introduced many species to Australia and New Zealand. Historian Thomas Dunlap describes the "perverse" "ecological imperialism" of the "European biological invasion" that occurred as colonists introduced dozens of European grasses, mammals, birds, shrubs and trees, as they "cut down forests, plowed prairies, and killed the native animals" (304; Franklin). For colonists in the early years, "even the birds, which a later generation would find beautiful and melodious, seemed deficient" (307).

As described by historian Brett Stubbs in "From 'useless brutes' to national treasures," by the late nineteenth century, the ambivalent relation to "native" fauna in Australia began to give way to discourses stressing protection of "native species." Ecological, nationalistic, and aesthetic desires including the "contribution of birds in the control of 
insect pests and a desire to protect beautiful and harmless species" drove changes in attitudes (Stubbs; Cushing and Markwell 604; Franklin). However, Cushing and Markwell suggest broad recognition of the "inherent value of native fauna as living creatures and the grave wrong of allowing those who were unique to Australia to become extinct" (604) did not occur until the early twentieth century. The "rise of nationalism and a growing identification with native nature" in the early twentieth century fostered greater appreciation for "native" fauna and a novel "myth of a new nation forged from the people's struggle with the 'bush'" (Dunlap 318; Robin). As independence from Britain increased, Adrian Franklin suggests, "nativeness was to be associated positively with the emergent nation and privileged over the introduced species ... the acclimatized 'foreigner' animals could be cast as endangering true Australian wildlife" (15). Consequently, cats increasingly became a concern of scientists in the early and mid-twentieth century. Science would eventually become the dominant means to control free-living cats that had flourished in Australian ecosystems.

By the turn of the twenty-first century, "eco-nationalism" became a dominant discourse in Australian environmentalism (Smith; Franklin). Eco-nationalism stresses a romantic ideal of nature that is uninterrupted by the destructive forces of human culture, and suggests that nature must be cleansed through the eradication of "invasive species," including feral cats. In this view, both ecologies and nations are managed based on notions of belonging that construct a dangerous "other" that is always waiting to invade, destroy, undermine, and threaten those that belong within a nation's borders. A related metaphor of war or invasion produces a state of exception that seeks to legitimize the protection of the nation from threatening "others" using any available methods, including border control, species cleansing, imprisonment, quarantine, and eradication. Nicholas Smith points to the power of invasive species discourses by noting that, in 1996, "West Australian Liberal Member of Parliament Richard Evans called for the eradication of all feral, stray and domestic cats in Australia by 2020" (288).

Cats were reported as preying on birds as early as 1886, as naturalist Andreas Reischek wrote of the stitch bird of New Zealand's Little Barrier Island, "these rare birds will soon disappear, even from these lonely wilds, owing to the domestic wild cats, which are very numerous, and commit great havoc on them" (87; Cheeseman). Ironically, in the same year the New South Wales Government "freighted four hundred cats by rail" as part of a broader strategy of releasing "thousands of domestic cats to combat the millions of rabbits threatening to destroy Australia's farming and grazing industry"

Humanimalia: a journal of human/animal interface studies

Volume 10, Number 2 (Spring 2019) 
(Smith 296). As cultural attitudes increasingly emphasized the value of "native nature," the cat would increasingly become a target of scientific and rhetorical wrath.

Don Merton, a famed conservation biologist, suggests that several natural historians observed cats killing considerable numbers of bird species in the Kermadic Islands, located northeast of New Zealand, around the turn of the twentieth century, perhaps resulting in the extinction of the Kermadec Parekeet and a "large indigenous fruit pigeon" (151). Zoologist Evan Turbott documents several efforts to destroy free-ranging populations of the domestic cat on Little Barrier Island as early as 1896 when "at least twenty cats were destroyed," and during the 1930s when "approximately 360 wild cats were confirmed as destroyed" (99). Despite these efforts, cats remained "in considerable numbers on all parts of the island in spite of vigorous efforts to destroy them by both shooting and trapping" (Ibid.). The extent that the early twentieth century efforts to eliminate free-living cats was associated with concerns related to bird populations in these local contexts is unclear, but does appear likely, especially in the context of rising concerns related to the protection of "native" species (Dunlap; Stubbs; Lloyd; Franklin). Following WWII, technoscience became increasingly central to the management of these antipodean environments and attempts to expand the reach of anthropocentric control to entire island ecologies (Dunlap).

By the 1970's, feral cats were garnering widespread association with declining populations of native birds in Australia and New Zealand as eradication efforts became clearly linked to concern for bird populations within the biological and ecological sciences. (Merton, "Kermadic Islands"; Dilks; Karl and Best). In 1978, Merton claimed that "fifteen biologically-important islands in the New Zealand region have been colonized by domestic cats; these predators are implicated in the extinction of at least 6 endemic New Zealand birds, as well as some 70 local extinctions" ("Controlling" 123). The source of Merton's data is unclear, but he responds to these circumstances by suggesting that "alien" species should be eradicated using "all available resources and all ecologically-acceptable means" ("Controlling" 127). Scientists increasingly began to suggest removal of free-living cats as necessary to the survival and revival of indigenous bird species. By 1978, Merton suggests the hunting and trapping of freeliving cats had eradicated the species from four islands, and additional extermination programs were in place on two additional islands. In fact, Merton points to increasing investment in eradication efforts, including a recent "large scale and long-term program of cat extermination using a combination of viral disease, trapping, poisoning, and hunting with dogs" ("Controlling" 124). As free-living cat populations came to be 
increasingly identified as a social problem, scientists helped to shape a sprawling institutionalized apparatus aimed at destroying these animals.

In his 1978 recommendations for controlling "alien" species Merton contrasts the rational methods of science with the emotions of a potentially critical public, as he writes "sound planning, including biological, political, social, financial, and logistic considerations, is crucial. Furthermore, field operations must always be preceded by thoughtfully-presented public relations programs in order to enlist public support and reduce emotional and misinformed criticism" ("Controlling" 127). By the 1970s, the annihilation of feral cats was taken as given for the rationally-minded scientist and sensible citizen, all arguments in opposition to this position were marked as "emotional" and "misinformed."

This recourse to rationality is reminiscent of Claude Bernard's justification for an objective detachment from his gory experimentation on animal bodies. Scientific accounts of cats as "alien" species deploy a detachment in their writing in describing the killing of dozens of cats as an "aerial baiting campaign" that "was responsible for the removal of at least $90 \%$ of the cats" (Algar et al. 139). Just as early colonists appealed to reason to justify the transport of cats to control rodent populations, post WWII ecologists and biologists appealed to rationality to justify their role in the killing and torture of cats.

As colonists brought cats to control rodent populations, they were seemingly unconcerned with the possible consequences of the invasion into new territories for local flora and fauna, just as colonists acted brutally towards indigenous peoples such as "beastlike" American Indians (Boggs). In the nineteenth century, on the one hand, cats were "humanized" as popular vehicles for Lockean moral pedagogy in the West that assumed compassionate treatment of animals would result in compassionate treatment of people. On the other hand, indigenous people were "animalized" to justify their rape and murder. As time passed, colonial cats in Australia and New Zealand were also "animalized" as "wild," "feral," "invasive," and "alien," partly reflecting ways nationalisms and "nature" intersected (Merton, "Controlling"; Lowe et al.; Robin). The subsequent treatment of these distinct groups aside, both the "humanized" and "animalized" cat, as well as the "animalized" aboriginal peoples, are constructed as less than human. In other words, the "human" is constructed as metaphysically superior to the "animal," reflecting human exceptionalist sensibilities that asymmetrically shape contemporary animalized bodies in part by constructing some bodies as rational and

Humanimalia: a journal of human/animal interface studies

Volume 10, Number 2 (Spring 2019) 
reasonable and others as emotional, illogical, misinformed, mindless, alien and beastlike.

Mastering nature. In 1970, Don Merton described "Raoul Island" as "biologically a great disappointment because the arrival of goats, cats, and more recently, Norway Rats ... has caused dramatic changes to the island's ecology" ("Kermadic Islands" 151). In Merton's account, the introduction of cats and rats by humans has thrown "nature" out of sorts, resulting in deleterious consequences. As a result, Merton refers to the cats as "alien" species that threaten "indigenous species" ("Controlling"). Recent popular articles including titles such as "The war on feral cats will need many different weapons" (Moseby and Read) and "Feral cats kill billions of small critters each year" (Nuwer) deploy similar language to suggest cats are a threat to "native" species, echoing nationalist and anti-immigration discourses (Subramaniam). As sociologist Adrian Franklin points out, the goal of ecology in matching the right organisms to an ecosystem reflects nationalistic policies that seek to match "the right people to the right territory" (17). By claiming "nature" is out of equilibrium, invasive species and antiimmigration discourses legitimize scientific and political intervention geared towards reconstructing ecosystems and societies based on changing cultural beliefs about who belongs in nature and nation.

Research in the 1970s and 1980s examined cat scat and revealed diets consisting primarily of rats (Dilks; Karl and Best). P.J. Dilks wrote of the limited bird remains found in cat scat, "except for one seabird, all of the vertebrate prey identified were species introduced to the island, and this reflects the present-day scarcity of indigenous species formerly found there" (65). Discussing the depleted stock of indigenous species, he continues, "feral cats are only one of the factors involved but their removal might allow the rehabilitation of some bird species" (66). Elimination of cats was controversial, in part because large rat populations also threatened bird populations by eating bird eggs and competing with birds for prey. Since rats were the primary food source for cats, the removal of cats could plausibly result in further hardship for bird populations. As Karl and Best stated simply, "removing cats from an island may allow the rat population to increase, which in turn might be detrimental to birdlife" (291). However, despite finding the remains of the flightless kakapo in only $5.1 \%$ of cat scat samples on Stewart Island in New Zealand, Karl and Best suggest the kakapo's chances of survival would probably "only be assured in a predator-free environment" (292). The more cautious language of Dilks relative to Merton's call for eradication suggests at least some scientific controversy regarding the most effective way for humans to manage these island ecosystems, especially in relation to free-living cat populations. As time 
passed, the language of invasion, crisis, and eradication became the norm, as an entire scientific apparatus came to wage a figurative and literal war on free-living cats. Felines were no longer welcome in the "nature" science had in mind. By 1985, free-living cats had reportedly been eliminated from eight islands in New Zealand as eradication efforts were increasingly "naturalized" as common sense (Rauzon 2). Evidence of any actual risks cats pose to Australian and New Zealand ecologies were unimportant within the metaphors of invasion and war. In fact, habitat destruction for human purposes is now widely considered a greater threat to indigenous species than introduced species, and the evidence that feral cats are the primary cause of declines in culturally valued species is questionable (Smith; Franklin).

Scientific accounts of these complex ecologies largely situate humans outside of these more "natural" processes. Despite the fact that Europeans literally brought these now loathed domestic cats to these ecosystems, scientists are portrayed as detached rational puppet masters making decisions based on scientific facts. Simply considering the colonial legacy of the cat suggests the importance of situating the human within these ecological systems, rather than as a detached observer capable of mastering nature. Instead, science might benefit from acknowledging the role of humans in continually making nature, or as Dunlap writes "remaking the land" (303). However, confronted with the unwillingness of other species and ecologies to meet desires for a precisely organized scientific dreamworld, science slogged forward in pursuit of progress towards the ultimate goal of mastering nature.

Technoscience, progress and poison. Domestic cats are now classified as one of the world's "100 worst invasive alien species" (Lowe et al.). In 2013, Loss and colleagues concluded that domestic cats kill 1.3-4.0 billion birds and 6.3-22.3 billion mammals in the United States annually - making domestic cats the largest source of human driven mortality of U.S. birds and mammals, as concern over feral cat populations articulates to new geographies. They acknowledge that the majority of the predation is the result of stray and feral cats, but that house cats are killers as well. The results of their work appeared in popular news media reports such as a Smithsonian publication (Nuwer).

The classification of cats as "invasive species" has produced deadly relationships between felines and technoscience, as various contemporary efforts to eradicate domestic cats have unfolded in these constructions. Eradication efforts are now aided by technoscientific baiting strategies, including the use of patented poisonous baits such as Eradicat ${ }^{\circledR}$ and Curiosity ${ }^{\circledR}$. As conservation scientist David Algar and colleagues describe in 2010, "Eradicat ${ }^{\circledR}$ is similar to a chipolata sausage,... the bait is composed of

Humanimalia: a journal of human/animal interface studies

Volume 10, Number 2 (Spring 2019) 
$70 \%$ kangaroo meat mince, $20 \%$ chicken fat and $10 \%$ digest and flavor enhancers" (134). Compound 1080 (sodium monoflouracetate) is injected into the kangaroo sausage to kill domestic cats if they bite into the delicious fat-oozing concoction. 1080 is the offspring of the U.S. Office of Scientific Research and Development, directed during World War II by Vannevar Bush (Ward). Bush provides an exemplary trope glorifying science in a letter to the President, writing

Science offers a largely unexplored hinterland for the pioneer who has the tools for his task. The rewards of such exploration both for the Nation and the individual are great. Scientific progress is one essential key to our security as a nation, to our better health, to more jobs, to a higher standard of living, and to our cultural progress. (vi)

For Bush, science is a limitless frontier of possibilities and progress. In extending Enlightenment visions of reason and progress, Bush's vision of science mirrors the work of colonial "pioneers" as they confronted "new and unexplored" lands and took "control" to develop the nation of Australia, according to popular discourses on British migrancy (Moreton-Robinson). As history illustrates, many ways of being and relating have been destroyed by Western progress narratives, as new "modernized" ways of being and relating have opened up for a small group of elite "humans." Further, the costs of speciesism and colonialism have included the aforementioned raping and murdering of indigenous peoples and mass killing of animals. In efforts to control freeliving cat populations, scientists have continued to trust a similar narrative that continued innovation and progress will eventually resolve the complex ecological and social problems they confront. Interspecies chemical warfare illustrates this faith, but marginalized bodies continually resist technoscientific desires.

Compound 1080 was tested in New Zealand as early as 1957 and was widely used after 1957 to control rabbits and possums (Rammell and Fleming). By 1978, 1080 was being used to poison cats in New Zealand primarily using fish baits (Veitch). From the late 1970s through 2000, compound 1080 was used to destroy cats on islands in New Zealand, Russia, Seychelles, Mexico, Great Britain, and Australia, including Matakohe, Marion, Fregate, Denis, Little Barrier, Isabela, Long Cay, Gabo, Hermite, and Macquarie (Nogales, et al.). In 1992, a dry pellet bait capable of remaining "palatable" to cats for over two weeks was tested as an improvement over the use of fresh fish (Eason et al.). The baits, including the polymer technology produced by DuPont, were determined to be a "high quality, highly palatable long-life bait," as the authors express hope "that these will become commercially available in the near future" (375). 
Then, in 1993, scientists associated with the Western Australian Department of Conservation and Land Management (CALM) began efforts to design "a bait medium that was attractive to feral cats, capable of carrying a toxin, relatively easy and cheaply manufactured and could be deployed aerially over broadscale areas" (Algar and Burrows 134). After experimentation, Kangaroo meat was determined to be a tasty lure for free-living cats, but technical problems with procuring uniform chunks of the meat led the team to turn to flesh in the form of sausage. The sausage was injected with 1080 to produce the lethal and "palatable" morsel. The design and development of the bait that came to be known as Eradicat ${ }^{\circledR}$ was "essentially completed in 1999" (Algar and Burrows 134) and resulted in an application for a patent in 2001 (Patent No. AU13682/01). Since the development of Eradicat ${ }^{\circledR}$, the bait has been used in many experiments, as well as contributing to the larger mission to eradicate cats from island ecosystems (Algar et al.; Algar, Angus, and Onus; Commonwealth of Australia).

Before deploying the tasty but deadly concoction of modern science in the mission of eradicating a population, the bait typically requires an application of Coopex® to repel ants from degrading the deployed bait (Algar and Burrows). Finally, the baits are typically dropped from aircraft. The 2015 Threat Abatement Plan published by the Commonwealth of Australia considers 1080 baits "a critical tool for the effective control of feral cats" (15). Yet, the use of these baits is controversial for a variety of reasons, including the potential of 1080 to poison "native" species, create unknown changes in ecologies, and enter into water supplies to perhaps eventually be consumed by humans (Suren; Sherley). Further, resistant scientists have argued that the use of 1080 is considered "inhumane" (Commonwealth of Australia 15), as McLeod and Sanders have shown that death from 1080 takes 4 to 24 hours and is caused typically by ventricular fibrillation or depression of the respiratory system (see also Sherley).

Australian statistician Clive Marks tragically recounts 1080 testing he conducted in pursuit of more humane ways to manage feral cats:

'Look,' I said and pricked the cat's leg with the probe once again, 'it responds to painful stimuli,' and on cue the cat twisted about and pawed unsteadily at the place where it had felt the pinprick. It fell once again upon its side and convulsed in turgid spasms and then stiffened, relaxed then stiffened again as it slowly rolled onto its back and cried until too paralyzed to vocalize.... This should not happen. Reams had been written and careers built upon fragile facts. According to the government websites carnivores do not suffer when they are poisoned with 1080. Yet, in truth,

Humanimalia: a journal of human/animal interface studies

Volume 10, Number 2 (Spring 2019) 
very few had ever seen the outcomes of using this poison on cats. We all knew that this was because no one really wanted to see. (55)

Marks's emotional reporting of collecting data as cats' lives slip away in experiments using 1080 unsettles the notion that the scientist must be detached from recognizing the sentience and worth of nonhuman lives.

Although the efficacy, safety, ecological effects, and morality of 1080 baiting is a topic of scientific debate, the use of the poison continues with variable levels of resistance in Australia and New Zealand. Ecologists Katherine Moseby and John Read write in support of the eradication efforts of the Australian government and the stated goal to kill two million cats by 2020. Arian Wallach and Daniel Ramp, scientists at the University of Technology Sydney, respond to Moseby and Read's support of cat eradication by arguing for accepting feline "immigrants as Australian citizens" in a call to reduce the suffering of cats (3). Wallach and Ramp challenge the notion that eliminating cats will lead to the ecological effects eradication proponents desire, suggesting instead that cats are now deeply entangled in complex ecosystems and removing them "will not be a clean and painless surgery, and it will not heal the patient" (2).

The 2015 Threat Abatement Plan of the Commonwealth of Australia describes "humane" methods of eradicating free-living cats, including properly executed "shooting," "trapping," and "baiting." Reflecting continued faith in science and technology to solve any social and ecological problem, the document describes possibilities of "fertility control" including hypothetical "immunocontraceptive vaccines" and "novel gene drive technologies" (16). The document does not discuss in any detail Trap-Neuter-Return (TNR) as a strategy for feline population management, despite an increase in laws requiring mandatory "de-sexing" for companion animals and widespread availability of "humane" de-sexing technologies (PETA, "Desexing").

As Susan McHugh points out, however, spay/neuter technologies emerged as an afterthought of eugenic practices in the early twentieth century, and have similarly been used primarily to serve "human self-interests"3 (116). In the U.S., the efficacy of TNR is a popular research topic for scientists concerned with managing free-living feline populations (Levy et al.; Longcore et al.). The lack of interest in TNR in Australia and New Zealand likely relates to cats being in remote, inaccessible areas, making them nearly impossible to trap. Nonetheless, the development of Eradicat ${ }^{\circledR}$, Curiosity ${ }^{\circledR}$, and hypothetical antidotes, immunocontraceptive vaccines, and gene-drive technologies 
serve the needs and desires of both scientists and financiers - prestige and profit, rationality and progress, life and death are all on the line.

The implosion of the Eradicat ${ }^{\circledR}$ bait reflects the troubling assumption that humans can control and master "nature," and reflects the emergence of a scientific mission to destroy free-living cat populations. Millions of dollars, countless hours of research, and hundreds of journal publications are related to the control of feral cat populations. In response to the threats 1080 poses to companion pets, the Invasive Animals Cooperative Research Centre began conducting research and development in 2015 on an antidote to toxins used in eradication efforts "for use with accidental poisoning of working and pet dogs" (Commonwealth of Australia). Eradicat ${ }^{\circledR}$ and Curiosity ${ }^{\circledR}$ have not killed the cat populations in Australia, but scientists continue pursuit of new artifacts such as robotic grooming traps that use machine learning to spray 1080 laced gels onto the fur of feline passersby so that cats ingest the poison as they groom their fur (Read et al.).

Cats have refused to cooperate with the imperatives of colonists and scientists - cats breed, kill, escape, and survive, despite the heavy artillery deployed to end feline lives. Resistant scientists, citizens, and activists struggle against the ever more sophisticated technologies that are explicitly designed to end some lives so that others might live. Since nonhumans fall outside of the purview of humanity, they are ever subject to the whims of science, capital, and human interest as knowledges are forged, resisted and changed regarding which nonhumans should be allowed to live and which will be targets of eradication. European disdain for indigenous Australian animals fueled major declines in populations in the early years of colonization, whereas today scientists aim to foster these self-same populations in an invasive species war.

Ending Progress. By deploying a posthumanist analytic and genealogical method, the history of the "domestic wild cats" of Australia and New Zealand has been put in relation to narratives of growth and progress, scientific hubris, rationality, speciesism, and colonialism. In many ways, this history is a microcosm of the legacy of Enlightenment rationality within contemporary technoscience. From colonial expansion to the twenty-first century, Curiosity ${ }^{\circledR}$ bait, and novel robotic grooming traps, human exceptionalism is firmly embedded within technoscientific entanglements of kangaroos, instruments, cats, persons, birds, and discourses. Human exceptionalism is a critical assumption of biopolitics and thanatopolitics because both people and animals can be "animalized" to legitimize death, torture, and interspecies war. Colonists and scientists sought to control their environment over the course of this history, deploying an ability to think "rationally" to solve particular problems at particular moments in time. This

Humanimalia: a journal of human/animal interface studies

Volume 10, Number 2 (Spring 2019) 
long arduous pursuit of progress has continuously wrought unforeseen consequences, including the possible extinction of many birds and killing of millions of free-living cats. "Non-humans" have continually refused the desires of colonists and technoscience. Technoscientific efforts to control and master environments are an enormous failure if judged in relation to the broad consequences of anthropocentric growth and progress, including climate change, water shortages, pollution, deforestation, extinctions, and soil erosion (Haraway, Staying; Weston; Puig de la Bellacasa; Frost). Ironically, many innovations aimed at addressing the human-made environmental devastation have wrought additional pollution, production, consumption, resource extraction, mass killings, and ecological crisis.

Kath Weston suggests that we are intimately entangled with a world in which our "finest technological achievements are implicated in habitat destruction" (10). She points to historically located intimacies people experience within a web of life, and stresses the need for a way out of the endless pursuit of profit, progress, and growth so often guised under the cloak of "rationality." She likens this tireless pursuit to the "dreamworld of the calculus" "with a boundary that logically and relentlessly approaches but cannot be breached through visceral experience" (179). As emotional attachment to the co-constituted pleasures, tropes, and routines of late capitalism "seduce people into participating in their own demise, often in the guise of working against it," she urgently calls for a recognition that, unlike the calculus, "organisms, ecologies, 'resources' - all these have their limits" (194).

The metaphor of war fosters emotional attachments to a mission to control ecosystems and eradicate invasive species. In naturalizing literal wars on animals including cats, possums, rats, and stoats, a state of exception fuels sentiments that prevent scientists and citizens from empathizing with the pain and suffering of the animals that are tortured and killed. Under threat of invasion and war, science must spare no cost and take any risk to eliminate the menacing "other." When science is governed by the demands of war, lethal and toxic discourses and artifacts are brought into being. As enemy species are attacked with all the toxic weapons science can assemble, the processes of overconsumption, deforestation, desertification, pollution, economic expansion, habitat destruction, and urban sprawl not only are obscured by the more immediate needs of war, but the war also further fuels corporate profits. These invasive species wars, for example, are justified based on economic benefits in programs such as the New Zealand government's Predator Free 2050 campaign. Technosciences shaped primarily by nationalist, aesthetic, economic, and speciesist desires currently fuel environmental ruin. How can science empathize with the pain of the nonhuman and 
recognize the destruction wrought by dreams of mastering nature in the interest of financial profit? How can knowledge be used to shape worlds without mobilizing a rhetoric of war to suggest that some lives are more valuable than others? The same scientific discourses that have fostered today's problems should not be allowed to try to innovate a way out of the trouble using the same assumptions and progress narratives that have caused a mess in the first place.

The actions, knowledges, and desires of bodies excluded from the status of "humanity" provide leadership in challenging the power of rational technoscience and calling forth worlds shaped by hopes of shared pleasures, intersubjectivity, mutual respect, and cross-species care. Although many Aboriginal peoples have historically been animalized and excluded from participation in the progress narratives of technoscience, Aborigines offer other ways of thinking and relating with nonhuman animals that challenge a metaphysics of human superiority. Adrian Franklin suggests Aborigines have ironically come to embrace introduced species such as feral cats as beings that now belong within a "natural world" that "does not exist as a separable world, beyond and different from the human world" (167). He continues, "unlike the scientist, they do not deal in absolute categories, classifications, boundaries pure and impure but in the messiness of life itself, in the complex way real life confounds the possibility of such a neat and ordered world" (167). Scientific efforts to order the world in its own image seek to cleanse landscapes of those bodies that supposedly do not belong. In contrast, although some animals were once strangers "to the country," Aborigines most frequently suggest cats belong in the "country" and even consider cats as "native animals" (173). Although the diversity of Aboriginal peoples' ways of thinking should not be reduced to any one perspective, these local knowledges suggests the possibility of human and nonhuman animals relating through mutual recognition, respect and response, opening up intersubjective ways of becoming and caring that are not possible in the context of scientific colonization, imperialism, or invasive species wars.

\section{Notes}

1. Australia and New Zealand have very different colonial histories and European settlers have had divergent relationships with indigenous peoples, nonhuman animals, and compound 1080. While outside the scope of the current genealogy, Australia and New Zealand have differing and changing approaches to the control and management of nonhuman animals in the twenty-first century. Both geographical locations are important in the history of the science and technology used in invasive species wars on feral cats and I have distinguished between these contexts throughout this paper using the language of Australia and New Zealand.

Humanimalia: a journal of human/animal interface studies

Volume 10, Number 2 (Spring 2019) 
2. Posthumanist ethics are often critical of animal rights ethics that may expand ethical consideration to nonhuman animals but reinforce a problematic human-animal binary by suggesting nonhuman animals lack a capacity for responsibility and agency and are unable to assume moral blame (For example see Blatz; Clement). Posthuman ethics acknowledge nonhuman agency and subjectivity within human-animal, socio-natural assemblages and posthumanists are more likely to promote ethics as a shared practice rather than set of rules (For example see: Puig de la Bellacasa; Haraway, When Species Meet and Staying with the Trouble).

3. See McHugh 115-119 for further discussion.

\section{Works Cited}

Abram, David. Becoming animal: An earthly cosmology. Vintage, 2010.

Algar, David, and Neil Burrows. "A Review of Western Shield: Feral Cat Control Research." Conservation Science Western Australia 5.2 (2004): 131-163.

Algar, David, Gary Angus, R. Brazell, C. Gilbert, and G. Withnell. "Eradication of Feral Cats on Faure Island, Western Australia." Journal of the Royal Society of Western Australia 93.3 (2010): 133-140.

Algar, David, Gary Angus, and M. Onus. "Eradication of Feral Cats on Rottnest Island, Western Australia." Journal of the Royal Society of Western Australia 94.3 (2011): 439- 443.

American Pet Products Association. "Pet Industry Market Size and Ownership Statistics" (2017). Online. Accessed 4 August 2018.

Berland, Jody. “Cat and Mouse." Cultural Studies. 22:3-4 (2008): 431-454.

Bernard, Claude. Introduction to the Study of Experimental Medicine. (1865). Trans. HC Greene. Henry Schuman, 1927.

Blatz, Charlie. "Mad bears and innocent hares: remarks toward a theory of diminished responsibility." Between the Species 3.1 (1987): 5.

Bunyak, Garrett. "Fat Cats and Porky Pooches: "Pet Obesity," Moral Panic, and Multispecies Possibilities." Society and Animals. Forthcoming. 
Bush, Vannevar. Science, the Endless Frontier: A Report to the President on a Program for Postwar Scientific Research. United States Government Printing Office, 1945.

Boggs, Colleen Glenney. Animalia Americana: Animal Representations and Subjectivity. Columbia UP, 2013.

Cheeseman, Thomas F. On the flora of the Kermadec Islands: with notes on the fauna. Transactions and Proceedings of the Royal Society of New Zealand, 1887. Online. Accessed 4 August 2018.

Clement, Grace. "The Ethic of Care and the Problem of Wild Animals." Between the Species 13.3 (2003). Online. Accessed 12 December 2018.

Commonwealth of Australia. "Background document for the threat abatement plan for predation by feral cats." 2015. Online. Accessed 12 December 2018.

Collard, Rosemary-Claire. “Apocalypse Meow." Capitalism Nature Socialism 24.1 (2013): 35-41.

Cudworth, Erika. "A Sociology for Other Animals: Analysis, Advocacy, Intervention." International Journal of Sociology and Social Policy, 36.3/4 (2016): 242257.

Cushing, Nancy, and Kevin Markwell. "The Bird was a Valuable One." Society $\mathcal{E}$ Animals 25.6 (2017): 592-609.

Dilks, P. J. "Observations on the food of feral cats on Campbell Island." New Zealand Journal of Ecology 2 (1979): 64-66.

Driscoll, Carlos A., David W. Macdonald, and Stephen J. O'Brien. "From Wild Animals to Domestic Pets, An Evolutionary View of Domestication." Proceedings of the National Academy of Sciences 106 (Supplement 1) (2009): 9971-9978.

Driscoll, Carlos A., Marilyn Menotti-Raymond, Alfred L. Roca, Karsten Hupe, Warren E. Johnson, Eli Geffen, Eric H. Harley, Miguel Delibes, Dominique Pontier, Andrew C. Kitchener, Nobuyuki Yamaguchi, Stephen J. O’Brein and David W. Macdonald. “The Near Eastern Origin of Cat Domestication." Science 317.5837 (2007): 519-523.

Humanimalia: a journal of human/animal interface studies

Volume 10, Number 2 (Spring 2019) 
Dunlap, Thomas R. "Remaking the Land: The Acclimatization Movement and Anglo Ideas of Nature." Journal of World History 8.2 (1997): 303-319.

Eason, Charles T., David R. Morgan, and B. Kay Clapperton. "Toxic bait and baiting strategies for feral cats." Proceedings of the Fifteenth Vertebrate Pest Conference, 1992.

Faure, Eric, and Andrew C. Kitchener. "An Archaeological and Historical Review of the Relationships Between Felids and People." Anthrozoös 22.3 (2009): 221-238.

Foucault, Michel, and François Ewald. "Society Must Be Defended": Lectures at the Collège de France, 1975-1976. Vol. 1. Macmillan, 2003.

Franklin, Adrian. Animal nation: The true story of animals and Australia. UNSW Press, 2006.

Frost, Samantha. Biocultural creatures: Toward a new theory of the human. Duke UP, 2016.

Grier, Katherine C. "Childhood Socialization and Companion Animals: United States, 1820-1870." Society \& Animals 7.2 (1999): 95-120.

Grzybowski, Andrzej, and Krzysztof Pietrzak. “David Hubel (1926-2013): The Man Who Developed Our Understanding of Vision." Neurological Science 35.6 (2014): 919-921.

Hasluck, Paul. Black Australians: A Survey of Native Policy in Western Australia, 1829-1897. Melbourne UP, 1970.

Haraway, Donna. J. The Companion Species Manifesto: Dogs, People, and Significant Otherness. Prickly Pear Press, 2003. . Modest_Witness@Second_Millenium.FemaleMan@_Meets_OncoMouseTM. Feminism and Technoscience. Routledge, 1997. . Staying With the Trouble: Making Kin in the Chthulucene. Duke UP, 2016. When Species Meet. U Minnesota P, 2008.

Hatch, Anthony R. Blood Sugar: Racial Pharmacology and Food Justice in Black America. U Minnesota P, 2016. 
The Humane Society of the United States. "Pets by the Numbers." Online. Accessed 23 January 2019.

Karl, Brian J., and Hugh Andrew Best. "Feral cats on Stewart Island; their foods, and their effects on kakapo." New Zealand Journal of Zoology 9.2 (1982): 287-293.

Koch, Katrin, David Algar, J.B. Searle, M. Pfenninger, and K. Schwenk. "A Voyage to Terra Australis: Human-mediated Dispersal of Cats." BMC Evolutionary Biology 15.1 (2015): 262.

Levy, Julie K., David W. Gale, and Leslie A. Gale. "Evaluation of the Effect of a Longterm Trap-neuter-return and Adoption Program on a Free-roaming Cat Population." Journal of the American Veterinary Medical Association 222.1 (2003): 42-46.

Loss, Scott R., Tom Will, and Peter P. Marra. "The Impact of Free-ranging Domestic Cats on Wildlife of the United States." Nature communications 4 (2013): 1396.

Lowe Sarah, M. Browne, S. Boudjelas, and M. De Poorter. 100 of the World's Worst Invasive Alien Species: A Selection from the Global Invasive Species Database. The Invasive SpeciesSpecialist Group (ISSG), 2000. Online. Accessed 12 December 2018.

Lloyd, Natalie. "'Among Birds and Beasts': Environmental Reform, Racial Preservation and Australian Progressives at the Zoological Gardens." Journal of Australian Studies 28.84 (2005): 43-51.

Longcore, Travis, Catherine Rich, and Lauren M. Sullivan. "Critical Assessment of Claims Regarding Management of Feral Cats by Trap-neuter-return." Conservation Biology 23.4 (2009): 887-894.

Marks, Clive. “Killing Schrödinger's feral cat.” Animal Studies Journal 2.2 (2013): 51-66.

McHugh, Susan. Animal Stories: Narrating across Species Lines. U Minnesota P, 2011.

McLeod, Lynette, and Glen Saunders. Pesticides Used in the Management of Vertebrate Pests in Australia: A Review. NSW Department of Primary Industries, Orange, 2013.

Humanimalia: a journal of human/animal interface studies

Volume 10, Number 2 (Spring 2019) 
Merton, Don V. "Kermadic Islands Expedition Reports: A General Account of Birdlife." Notornis 17.3 (1970): 147-199.

. "Controlling Introduced Predators and Competitors on Islands." Endangered Birds: Management Techniques for Preserving Threatened Species. Stanley A. Temple, Ed. U Wisconsin P, 1978. 121-128.

Moreton-Robinson, Aileen. "I Still Call Australia Home: Indigenous Belonging and Place in a White Postcolonizing Society." Uprootings/regroundings: Questions of Home and Migration (2003): 23-40.

Moseby, Katherine and John Read. "The War on Feral Cats Will Need Many Different Weapons." The Conversation July 23, 2015. Online. Accessed 12 December 2018.

New Zealand Companion Animal Council Inc. Companion Animals in New Zealand 2016. Auckland, New Zealand. (2016). Online. Accessed 12 December 2018.

Nogales, Manuel, Aurelio Martin, Bernie R. Tershy, C. Josh Donlan, Dick Veitch, Nestor Puerta, Jill Wood, and Jesus Alonso. "A review of feral cat eradication on islands." Conservation Biology 18.2 (2004): 310-319.

Nuwer, Rachel. "Feral Cats Kill Billions of Small Critters Each Year." Smithsonian.com, January 29, 2013. Online. Accessed 12 December 2018.

People for the Ethical Treatment of Animals. "Desexing and Microchipping Will be Mandatory in South Australia!" PeTA Australia, 21 July 2016. Online. Accessed 12 December 2018.

People for the Ethical Treatment of Animals. "Cats in Laboratories." PeTA, 2017. Online. Accessed 12 December 2018.

Potts, A. A New Zealand Book of Beasts: Animals in our Culture, History and Everyday Life. Auckland UP, 2013.

Puig de la Bellacasa, Maria. Matters of Care: Speculative Ethics in More than Human Worlds. U Minnesota P, 2017. 
Rauzon, Mark. "Feral Cats on Jarvis Island: Their Effects and Their Eradication." Atoll Research Bulletin 282 (1985): 1-30.

Rammell, Colin G., and Peter A. Fleming. "Compound 1080. Properties and Use of Sodium Monofluoroacetate in New Zealand." Ministry of Agriculture and Fisheries, Wellington, New Zealand (1978).

Read, J., Frank Gigliotti, Sue Darby, \& Steven Lapidge. “Dying to be clean: pen trials of novel cat and fox control devices." International Journal of Pest Management 60.3 (2014): 166-172.

Reischek, Andreas. "Notes on New Zealand Ornithology." Transactions and Proceedings of the New Zealand Institute 19 (1886). 187-198.

Robin, Libby. "Nationalising Nature: Wattle Days in Australia." Journal of Australian Studies 26.73 (2002): 13-26.

Robins, Sandy. "A History of Cat Domestication: When and Where Felines Went from Wild Animals to Adored Companions." Animal Behavioral College Blog, March 12016. Online. Accessed 12 December 2018.

Rose, Nikolas. The Politics of Life Itself: Biomedicine, Power, and Subjectivity in the Twentyfirst Century. Princeton UP, 2007.

RSPCA Australia. RSPCA Australia National Statistics 2016-2017. Accessed 23 January 2019.

Sherley, Miranda. "Is sodium fluoroacetate (1080) a humane poison?" Animal Welfare 16.4 (2007): 449.

Shew, Ashley. Animal Constructions and Technological Knowledge. Lexington Books, 2017.

Smith, Nicholas. "The howl and the pussy: feral cats and wild dogs in the Australian imagination." The Australian Journal of Anthropology 10.3 (1999): 288-305.

Stubbs, Brett J. "From 'Useless Brutes' to National Treasures: A Century of Evolving Attitudes Towards Native Fauna in New South Wales, 1860s to 1960s." Environment and History 7.1 (2001): 23-56.

Humanimalia: a journal of human/animal interface studies

Volume 10, Number 2 (Spring 2019) 
Subramaniam, Banu. Ghost Stories for Darwin: The Science of Variation and the Politics of Diversity. U Illinois P, 2014.

Suren, Alastair M. "Quantifying Contamination of Streams by 1080 Baits, and Their Fate in Water." New Zealand Journal of Marine and Freshwater Research 40.1 (2006): 159-167.

Suzdaltsev, Jules. "A Brief History of Scientific Experiments on Cats." Vice, February 11, 2015. Online. Accessed 12 December 2018.

Turbott, Evan G. “Birds of Little Barrier Island.” New Zealand Bird Notes 2.92 (1947): 108.

Veitch, Charles R. "The Eradication of Feral Cats (Felis catus) from Little Barrier Island, New Zealand." New Zealand Journal of Zoology 28.1 (2001): 1-12.

Vogt, Amy H., Ilona Rodan, Marcus Brown, Scott Brown, Tony Buffington, LaRue Forman, and Andrew Sparkes. "AAFP-AAHA: feline life stage guidelines." Journal of the American Animal Hospital Association 46 (2010): 70-85. Online. Accessed 12 December 2018.

Wadiwel, Dinesh Joseph. "Thick Hides: Whipping, Biopolitics and the White Soul of Power." Social Semiotics 19.1 (2009): 47-57.

Wallach, Arian, and Daniel Ramp. "Let's give feral cats their citizenship." The Conversation, 2015. Online. Accessed 12 December 2018.

Ward, Justus C., and D. A. Spencer. "Notes on the Pharmacology of Sodium Fluoroacetate - Compound 1080." Journal of the American Pharmaceutical Association (Scientific ed.) 36.2 (1947): 59-62.

Weston, Kath. Animate Planet: Making Visceral Sense of Living in a High-Tech Ecologically Damaged World. Duke UP, 2016. 